\title{
Institutional Industry Herding: Intentional or Spurious?
}

\author{
Constantinos Gavriilidis $^{\mathrm{a}}$, Vasileios Kallinterakis ${ }^{\mathrm{b}, *}$ and Mario Pedro Leite Ferreira ${ }^{\mathrm{c}}$ \\ ${ }^{a}$ Durham Business School, Mill Hill Lane, Durham DH1 3LB, UK \\ bUniversity of Liverpool Management School, Chatham Building, Chatham Street, Liverpool L69 7ZH, UK \\ ${ }^{\mathrm{c}}$ Universidade Católica Portuguesa, Centro Regional do Porto, Rua Diogo Botelho, 1327, 4169-005 Porto, Portugal
}

\begin{abstract}
The present paper aims at investigating the extent to which institutional herding at the industry level is motivated by intent or not. We assess the presence of intent using both market and sector states based on three variables (returns; volatility; volume), in order to gauge whether herding intent at the sector level is more relevant to conditions prevailing in a sector or the market as a whole. Using a unique database of quarterly portfolio holdings of Spanish funds, we produce evidence denoting that institutional herding in the Spanish market is intentional for most sectors, manifesting itself mainly during periods when the market as a whole or the specific sector under examination has underperformed, generated rising/high volatility and exhibited rising/high volume.
\end{abstract}

Keywords: institutional investors; industry herding; intent; Spain

JEL Classification: G01; G02; G10; G15; G23

* Corresponding author. Email: V.Kallinterakis@liverpool.ac.uk 


\section{Introduction}

The possibility of fund managers herding at the industry level has been explored by a series of studies, with evidence from the extant research confirming the presence of institutional industry herding for several markets internationally (e.g. Voronkova and Bohl, 2005; Choi and Sias, 2009; Chen et al, 2012). An interesting question here is whether the observed industry herding results from funds following each other intentionally into and out of industries or not. A second question arising from the above is whether the presence of intent in industry herding is related to the specific conditions of each industry or whether the conditions of the market as a whole are also capable of promoting it. It is these two issues the present study aims at addressing.

From a theoretical perspective, herd behaviour involves the propensity of investors towards mimicking the trades of their peers following observation of their actions and their actions' payoffs (Hirshleifer and Teoh, 2003). Although retail investors would be expected to be more susceptible to behavioural biases in their trades, there exists ample evidence in the literature lending support to the existence of herding on behalf of professional investors which has been attributed to both intentional and spurious motives (Bikhchandani and Sharma, 2001). For a professional investor to herd intentionally, his herding needs to be motivated through a) a relative view of his position versus his peers and b) the anticipation of a positive externality (i.e. a payoff). It is possible, for example, that fund managers choose to herd because they expect to reap informational payoffs (Devenow and Welch, 1995); this is the case when an investor follows others because he thinks that they are in possession of better information or better information-processing skills. If this becomes widespread practice, it can compromise a market's informational efficiency, since it will result in temporary blockades in the aggregation of information into prices (those herding are not trading on their information, hence the latter is not reflected into securities' prices) and, in the extreme, lead to informational cascades (Banerjee, 1992; Bikhchandani et al, 1992). It is also possible that investment professionals herd intentionally motivated by career/reputational payoffs (Trueman, 1994; Clement and Tse, 2005). With the performance of fund managers being assessed relatively (i.e. versus their peers), a fund manager lacking confidence in his skills has every interest in copying the trades of his better able peers, since this will allow him to conceal his low ability. Such behaviour distorts the 
assessment process, with those in charge of it finding it difficult to decipher whether a fund manager's good performance is due to his skills or due to him mimicking his "good" peers (Scharfstein and Stein, 1990). However, the presence of factors common among investment professionals may lead fund managers to exhibit correlation in their trades, thus generating the impression of herding, without the latter being due to intent (spurious herding). Such correlation can be the result of fund managers being characterized by relative homogeneity (De Bondt and Teh, 1997) given their common features (similarities in their educational background, investment experience, the signals they receive and their processing) and the common regulatory framework they are subject to (Voronkova and Bohl, 2005). Another possibility is that what comes across as herding may in fact be the result of style investing (e.g. Bennett et al, 2003); if several funds, for example, are momentum-trading, it is likely that they herd into recent winners and out of recent losers.

The identification of the above motives underlying institutional herding prompted a surge in the number of studies undertaken with the purpose of establishing its presence empirically. In the past two decades, research has been extensive on this issue, with evidence from a multitude of markets internationally confirming that fund managers do indeed engage in peer-mimicking in their trading conduct. More specifically, institutional investors have been found to herd significantly in a rather diverse set of markets, including Germany (Walter and Weber, 2006; Kremer and Nautz, 2011), Portugal (Holmes et al, 2011), Taiwan (Chen et al, 2012), the UK (Wylie, 2005) and the US (e.g. Lakonishok et al, 1992; Wermers, 1999; Sias, 2004; Choi and Sias, 2009).

However, the bulk of empirical herding research has treated the above mentioned (intentional and spurious) herding motives as a set of theoretical explanations underlying the herding of fund managers, with very little attention having been devoted to the empirical identification of intent itself. Holmes et al (2011) first proposed an approach aiming at deciphering empirically whether fund managers herd intentionally or not. The crux of their argument was that if institutional herding were intentional, its significance would exhibit variations between different states of the market; conversely, if fund managers herded spuriously, their herding would be expected to be significant irrespective of the market's state. To that end, they put forward a series of hypotheses linking herding 
intent with specific market conditions related to variables such as market returns, market volatility and regulatory changes and tested them in the context of the Portuguese market. The findings they reported indicated that Portuguese fund managers did not herd indiscriminately but rather that their herding grew in significance when the market underwent specific conditions (i.e. they herded intentionally). Holmes et al's (2011) results demonstrated how herding intent could be traced in the market environment through the impact of this environment's variations over herding significance. However, institutional herding need not take place exclusively at the market level or be solely driven by the conditions prevailing at that level. An example is the ample evidence (Voronkova and Bohl, 2005; Choi and Sias, 2009; Chen et al, 2012) indicating that fund managers herd significantly when investing in industries. Since the key herding motives (intentional and spurious) mentioned previously are as much influential on fund managers' decision to herd at the industry level as they are at the individual stock level (Choi and Sias, 2009), the Holmes et al (2011) approach described above can be applied to assess the presence of intent in institutional industry herding. Nevertheless, the assessment of intent at the industry level requires the identification of environmental states upon which institutional herding will be conditioned. Holmes et al (2011) tested for intent on the premises of different market states because their study investigated herding at the market level; testing for intent at the industry level requires that one takes into consideration the specific conditions of each industry as well as those of the market, since industries are subject both to their own dynamics (due e.g. to their specific structure, regulatory environment or fundamentals) as well as to the market's (they constitute parts of it). Resorting to market conditions alone to detect herding intent at the industry level is bound to miss out on important information conveyed through sector conditions, since the latter are more representative of the activity surrounding an industry (Demirer and Kutan, 2006) and should be more relevant to the investments of fund managers relative to that sector (Frazzini and Lamont, 2008).

The present paper tests whether institutional industry herding is intentional or not for the first time in the literature controlling for a variety of states corresponding to both the market as a whole as well as each individual sector. We explore the presence of institutional herding intent at the sector level in the context of the Spanish market using quarterly portfolio-holdings data of the country's mutual funds. 
Specifically, the states we control for to test for intent are based on three variables (returns; volatility; volume), each pertaining to each sector separately and the market as a whole. Our research aims at addressing the following two questions:

- Do fund managers herd intentionally at the industry level?

- Is the intent underlying their industry herding related to the specific conditions of each industry or are market conditions also capable of promoting it?

In summary, our results indicate that Spanish fund managers herd significantly at the overall market level, while the interactions of their herding in each sector with these states reveal that fund managers herd significantly in most industries mainly during periods when the market as a whole or the specific sector under examination has underperformed, generated rising/high volatility and exhibited rising/high volume. These findings denote the presence of intent in institutional industry herding and we show how this is linked to informational and career-related herding motives.

Our research contributes to the existing herding literature by providing evidence for the first time on institutional industry herding being intent-driven and demonstrating that it is both market as well as sector conditions underlying this intent. This is interesting from an investor's viewpoint, since being aware of the conditions that promote herding among funds investing in a sector can constitute a potentially useful input to any sector-style strategy. Regarding regulators, these results denote that the intent underlying institutional industry herding is versatile in nature, motivated by different marketwide and sector-specific factors for each sector; such knowledge can be particularly important to them when considering measures aiming at curtailing fund managers' herding tendencies in order to avoid their potentially destabilizing effects (Goodhart et al, 1999; Economou et al, 2011).

The next section will provide a detailed presentation of the market/sector variables used to control for herding intent, as well as describe the database employed in our research and the methodology used. Section 3 presents and discusses the results and section 4 concludes. 


\section{Data and Methodology}

Our study is based on a unique database of quarterly portfolio holdings of Spanish mutual funds covering the June 1995 - September 2008 period, obtained from the Spanish Securities Markets Commission (Comisión Nacional del Mercado de Valores - CNMV). Our sample consists of 1543 mutual funds which have invested in 245 domestic (i.e. Spanish) stocks at any point in time during our sample period. The dataset at hand provides us with information on the code and name of each fund, the code and name of its portfolio's assets each quarter and the number of shares of each asset it holds. Table 1 presents some descriptive statistics regarding Spanish funds' holdings both for the full sample as well as each of the nine sectors we have identified. As the table shows, the average number of stocks traded actively by at least one fund is 79.9 for the whole period, peaking in 1999 to 100.1 and declining to 83.2 by 2010 . Likewise, the average number of active funds per stock for the whole period is 136.6, reaching a peak in 1999 (156) and falling to 135.3 by 2010 . This pattern tracks the course of the Spanish stock market (which peaked in early 2000 only to crash later following the Dot Com bubble's burst in spring 2000 in the US) and is also encountered in most of our sample's sectors.

To measure institutional herding we adopt the empirical framework proposed by Sias (2004) which identifies herding through the intertemporal dependence of institutional demand, the latter being calculated as the raw fraction of funds increasing their position (i.e. buying) in security $k$ during period (in our case, quarter) $t$ :

$\operatorname{Raw} \Delta_{\mathrm{k}, \mathrm{t}}=\frac{\text { No.of Funds Buying Security } \mathrm{k} \text { in quarter } t}{\text { No.of Funds Buying Security } \mathrm{k} \text { in quarter } t+\text { No.of Funds Selling Security } k \text { in quarter } t}$

Sias (2004) then standardizes $\operatorname{Raw} \Delta_{k, t}$ :

$\Delta_{\mathrm{k}, \mathrm{t}}=\frac{\operatorname{Raw} \Delta_{k, t}-\overline{\operatorname{Raw} \Delta_{t}}}{\sigma\left(\text { Raw } \Delta_{k, t}\right)}$

where, $\overline{\operatorname{Raw} \Delta_{t}}$ is the cross-sectional average raw fraction of institutions buying in quarter $t$ and $\sigma\left(\operatorname{Raw} \Delta_{k, t}\right)$ is the cross-sectional standard deviation of the raw fraction of institutions buying in 
quarter $t$. To test for the existence of herding, Sias (2004) assumes institutional demand to follow an autoregressive process of order one:

$\Delta_{k, t}=\beta_{t} \Delta_{k, t-1}+\varepsilon_{k, t}$

The first-order autocorrelation coefficient $\left(\beta_{\mathrm{t}}\right)$ here reflects the quarter-on-quarter cross-sectional correlation between institutional demand in quarter $\mathrm{t}$ and quarter $\mathrm{t}-1$, since both sides of equation (3) are standardized and there is only one independent variable $\left(\Delta_{k, t-1}\right)$ on the right-hand side of the equation. Sias (2004) then decomposes $\beta_{\mathrm{t}}$ into that part due to funds following their own trades and another one due to funds following the trades of other funds. More specifically, $\beta_{\mathrm{t}}$ is decomposed as follows:

$$
\begin{aligned}
& \left.\beta_{\mathrm{t}}=\rho\left(\Delta_{\mathrm{k}, \mathrm{t}} \Delta_{\mathrm{k}, \mathrm{t}-1}\right)=\left[\frac{1}{(K-1) \sigma\left(\operatorname{Raw} \Delta_{\mathrm{k}, \mathrm{t}}\right) \sigma\left(\operatorname{Raw} \Delta_{\mathrm{k}, \mathrm{t}-1}\right.}\right)\right] \times \sum_{k=1}^{k=K}\left[\sum_{n=1}^{N_{\mathrm{k}, \mathrm{t}}} \frac{\left(D_{\mathrm{n}, \mathrm{k}, \mathrm{t}}-\overline{\operatorname{Raw} \Delta_{\mathrm{t}}}\right)\left(D_{\mathrm{n}, \mathrm{k}, \mathrm{t}-1}-\overline{\operatorname{Raw} \Delta_{\mathrm{t}-1}}\right)}{N_{\mathrm{k}, \mathrm{t}} N_{\mathrm{k}, \mathrm{t}-1}}\right] \\
& +\left[\frac{1}{(K-1) \sigma\left(\operatorname{Raw} \Delta_{\mathrm{k}, \mathrm{t}}\right) \sigma\left(\operatorname{Raw} \Delta_{\mathrm{k}, \mathrm{t}-1}\right)}\right] \times \sum_{k=1}^{k=K}\left[\sum_{n=1}^{N_{\mathrm{k}, \mathrm{t}}} \sum_{m=1, m \neq n}^{N_{\mathrm{k}, \mathrm{t}-1}} \frac{\left(D_{\mathrm{n}, \mathrm{k}, \mathrm{t}}-\overline{\operatorname{RaW} \Delta_{\tau}}\right)\left(D_{\mathrm{m}, \mathrm{k}, \mathrm{t}-1}-\overline{\operatorname{Raw} \Delta_{\mathrm{t}-1}}\right)}{N_{\mathrm{k}, \mathrm{t}} N_{\mathrm{k}, \mathrm{t}-1}}\right]
\end{aligned}
$$

$\mathrm{N}_{\mathrm{k}, \mathrm{t}}$ is the number of funds actively trading security $k$ in quarter $t$ and $\mathrm{D}_{\mathrm{n}, \mathrm{k}, \mathrm{t}}$ is a dummy variable taking the value of one when fund $n$ is a buyer of security $k$ in quarter $t$ and zero when fund $n$ is a seller of security $k$ in quarter $t$. Likewise, $\mathrm{N}_{\mathrm{k}, \mathrm{t}-1}$ is the number of funds actively trading security $k$ in quarter $t-1$ and $\mathrm{D}_{\mathrm{n}, \mathrm{k}, \mathrm{t}-1}$ is a dummy variable equal to one when fund $n$ is a buyer of security $k$ in quarter $t-1$ and zero when fund $n$ is a seller of security $k$ in quarter $t-1 . \mathrm{D}_{\mathrm{m}, \mathrm{k}, \mathrm{t}-1}$ is a dummy variable that equals one when fund $\mathrm{m}(\mathrm{m} \neq \mathrm{n})$ is a buyer of security $k$ in quarter $t-1$ and zero when fund $\mathrm{m}(\mathrm{m} \neq \mathrm{n})$ is a seller of security $k$ in quarter $t-1$. The first term on the right-hand side of the above equation is the portion of the correlation due to funds following their own trades; if it is positive (negative), then funds tend to follow (reverse) their trades over adjacent quarters. The second term on the right-hand side of the above equation is the portion of the correlation due to funds following the trades of other funds; if it is positive (negative), then funds tend to follow (trade against) each other over adjacent quarters.

Equations (3) and (4) are estimated both for the universe of our sample's stocks as well as for each of our nine sectors. To gauge now whether institutional industry herding is intentional or not, we follow 
the approach of Holmes et al. (2011) which traces intent through the interaction of institutional herding with different states of the trading environment. We examine the presence of intent in our paper using three variables (returns; volatility; volume) in both their market and sector expressions ${ }^{1}$.

Market/sector returns: the relative nature of institutional investors' performance assessment (they are normally assessed versus their peers) renders herding a viable option for "bad" (i.e. low quality) fund managers as it allows them to conceal their weak ability by imitating the actions of their "good" counterparts. The importance of this is expected to be more pronounced during periods of declining prices, since it is during those periods that investors are more likely to generate losses and, consequently, face assessment issues. Since bearish conditions lead everyone in the market to perform poorly, herding on the trades of "good" managers allows "bad" managers to share the blame: despite them making "good" decisions (in the sense that, they traded the same stocks as their "good" peers), they still underperformed as a result of the prevailing bearish conditions. Such behaviour obviously jams the assessment process, rendering it difficult for the assessors to distinguish between high- and low-quality managers, while on the other hand giving "bad" managers the opportunity to conceal their low quality. Bullish conditions can, however, also prompt "bad" managers to herd intentionally, since underperforming during periods of rising prices is more easily associated to low ability. If institutional industry herding is intentional, we would expect to trace a relationship between market/sector returns and institutional industry herding (i.e. institutional industry herding would exhibit differences between bearish and bullish periods); if fund managers herded spuriously, no such differences would be expected to arise ${ }^{2}$. To test for the effect of market/sector returns over institutional industry herding we use the quarter-end closing prices of the Madrid Stock Exchange General Price Index and our nine sector indices for the June 1995 - September 2008 period, calculate their quarterly log-differenced

\footnotetext{
${ }^{1}$ All data used to calculate the market and sector expressions of the three variables were obtained from Thomson-Reuters DataStream. The Madrid Stock Exchange General Price Index (DataStream mnemonic: MADRIDI) is used to calculate all market expressions of these variables; their sector expressions are calculated on the basis of the following sector-indices (DataStream mnemonics in brackets): Basic Materials (BMATRES); Consumer Goods (CNSMGES); Consumer Services (CNSMSES); Financials (FINANES); Healthcare (HLTHCES); Industrials (INDUSES); Oil and Gas (OILGSES); Technology (TECNOES); Utilities (UTILSES).

${ }^{2}$ If relative homogeneity drives herding and changes in the market's/sector's return quarter-on-quarter affect herding, this would suggest that the composition of institutional investors as a group varies significantly from one quarter to the next which is probably something unrealistic to assume. If it is style investing that drives herding, then we would expect the performance of the market/sector to bear an effect over the profitability of style strategies, yet not affect the level of style investing (i.e. the tendency of investors to style-invest).
} 
returns and rank the return-series of each index in ascending order. Following that, we split the returnseries of each index in two different ways, one relative and one absolute. In the former case, we split each return-series into two parts, contingent upon whether a quarter's returns are positive or negative (i.e. whether the market or the sector index has risen/declined in quarter t compared to quarter $\mathrm{t}-1$ ) and then split $\beta_{\mathrm{t}}$ and its two components (funds following their own trades; funds following the trades of other funds) of each sector accordingly. In the latter case, we break up each return-series into three parts, namely "high" (containing the top third of the market/sector index returns), "mid" (containing the middle third of the market/sector index returns) and "low" (containing the bottom third of the market/sector index returns) and then break up $\beta_{\mathrm{t}}$ and its two components of each sector accordingly.

Market/sector volatility: the presence of high or increased volatility in a market has been associated (Ross, 1989) with an increase in informed trading, in the sense that a higher flow of information to the market leads prices to be more volatile as this information is incorporated to them. A highly informative environment is obviously not conducive to herding, since there exists more information on which investors can trade. However, "bad" managers may view such a situation from a different perspective, as an increase in information-flow can lead the market environment to grow in complexity; in that case, deciphering the content of information may require skills that "bad" managers are not expected to possess, thus ending up mimicking their "good" peers. However, tranquil periods can also prompt "bad" managers to resort to herding, as the lack of turbulence renders it easier for them to visualize the trades of their "good" peers. If fund managers herd intentionally at the industry level, we would expect a relationship to evolve between market/sector volatility and institutional industry herding (institutional industry herding would exhibit differences between more volatile and less volatile periods); if fund managers herded spuriously, one would expect no such differences $^{3}$. To test for the effect of market/sector volatility over institutional industry herding we use the daily closing prices of the Madrid Stock Exchange General Price Index and our nine sector indices for the June 1995 - September 2008 period, calculate the volatility of each index every quarter using the Schwert (1989) approach and then rank these quarterly volatility observations of each index in

\footnotetext{
${ }^{3}$ The quarterly variations in market/sector volatility would not be expected to lead to variations in either the relative homogeneity among fund managers, or the level of style investing practiced.
} 
ascending order. Following that, we split each volatility-series in two different ways, one relative and one absolute. In the former case, we split each volatility-series into two parts, contingent upon whether a quarter's volatility has risen/declined in quarter t compared to quarter $\mathrm{t}-1$ and then split $\beta_{\mathrm{t}}$ and its two components of each sector accordingly. In the latter case, we break up each volatilityseries into three parts, namely "high" (containing the top third of the market/sector volatility values), "mid" (containing the middle third of the market/sector volatility values) and "low" (containing the bottom third of the market/sector volatility values) and then break up $\beta_{\mathrm{t}}$ and its two components of each sector accordingly.

Market/sector volume: the presence of increased or high volume of trade reduces liquidity risk, thus allowing informed investors to trade more easily on their information as they can see their trades more easily executed (Romano, 2007). With "good" managers being the natural candidates for the role of informed traders, this means that high volume renders their trades more visible to "bad" managers who can thus copy them. However, a fund manager would seriously consider investing in the same stocks as his peers during periods of relatively low liquidity as well in order to shield himself against liquidity risk. This is because the absence of sufficient volume in a stock prevents a trader from selling it in case the stock underperforms; holding the same stocks as his peers reduces this problem, since stocks traded by several funds together are expected to enjoy higher volumes. Consequently, if there is intent on behalf of fund managers in their industry herding, we would expect to find a relationship between their industry herding and trading volume (i.e. institutional industry herding would exhibit differences between periods which are more and periods which are less liquid); however, if their herding were spurious, one would not expect to encounter such differences ${ }^{4}$. To test for the effect of market/sector volume over institutional industry herding we use the daily volume observations of the Madrid Stock Exchange General Price Index and our nine sector indices for the June 1995 - September 2008 period, aggregate the daily volume observations each quarter for each index and then rank the quarterly volume observations of each index in ascending order. Following that, we split each volume-series in two different ways, one relative and one absolute. In the former

\footnotetext{
${ }^{4}$ The quarterly variations in market/sector volume would not be expected to lead to variations in either the relative homogeneity among fund managers, or the level of style investing practiced.
} 
case, we split each volume-series into two parts, contingent upon whether a quarter's volume has risen/declined in quarter $\mathrm{t}$ compared to quarter $\mathrm{t}-1$ and then split $\beta_{\mathrm{t}}$ and its two components of each sector accordingly. In the latter case, we break up each volume-series into three parts, namely "high" (containing the top third of the market/sector volume values), "mid" (containing the middle third of the market/sector volume values) and "low" (containing the bottom third of the market/sector volume values) and then break up $\beta_{\mathrm{t}}$ and its two components of each sector accordingly.

\section{Results - Discussion}

Before examining whether institutional industry herding is intentional or not, we will first take a look at our full-sample results, both for the market level as well as for each sector individually which are presented in Table 2. At the overall market level, the demand of Spanish funds for domestic stocks bears a significant ${ }^{5}$ temporal dependence (reflected through the $\beta_{t}$ coefficient) which is strongly motivated by herding (reflected through the "funds following the trades of other funds" part) rather than habit investing (the "funds following their own trades" part is insignificant). The only other occasion where $\beta_{t}$ appears significant in table 2 is for Technology, for which both $\beta_{t}$-components are significant, while significant herding is detected for Consumer Services and Industrials. The first picture therefore obtained from our full-sample results is that Spanish funds herd significantly, with their herding significance identified with Consumer Services, Industrials and Technology.

We now move on to assess whether institutional herding at the sector level is due to intent or not by examining its interactions with a series of market and sector states based on three variables (returns; volatility; volume). To begin with, we first assess the impact over institutional industry herding of the relative change in the quarterly returns of both the market index as well as the index of the sector under consideration. Results are reported in table 3, where it appears that $\beta_{t}$ is significant mostly during quarters of negative market (Financials; Oil and Gas; Technology) and sector (Consumer Services; Financials; Industrials; Technology) performance ${ }^{6}$. Habit investing seems stronger during underperforming sector quarters (the "funds following their own trades" part is significant for Oil and

\footnotetext{
${ }_{6}^{5}$ Any reference to statistical significance from now on will refer to estimates significant at either the 5 or 1 percent levels.

${ }^{6}$ For Technology stocks, $\beta_{t}$ is also significant during quarters of positive market and sector performance.
} 
Gas and Technology for those quarters) while for Oil and Gas it is also significant during negative market quarters. In terms of herding, the "funds following the trades of other funds" part is significant for Consumer Services during quarters of positive market returns and negative sector returns; for both Financials and Industrials, the estimates of that part are significant during quarters of negative market returns and negative sector returns. The above indicate that the significance of institutional industry herding is stronger during quarters when either the market or the sector have performed poorly, suggesting that it is intentional in line with what we mentioned in the previous section. Technology stocks exhibit significant institutional herding irrespective of the quarterly performance of the market or their sector (the "funds following the trades of other funds" part is significant in all tests) thus denoting the absence of herding intent there; no herding significance is detected for the other sectors.

The link between institutional industry herding and negative market/sector returns is further confirmed in table 4 which presents the estimates from the break-up of $\beta_{t}$ and its two components into three parts (high-mid-low market/sector index returns). To facilitate the discussion, we begin from the Technology sector, whose $\beta_{t}$-estimates and "funds following the trades of other funds" estimates are significant for all tests, indicating that the demand of Spanish funds for Technology stocks is strongly herding-driven, again however, without intent underlying their herding. Aside from the Technology sector, the significance of $\beta_{t}$ is manifested only for Consumer Services during quarters of low market returns; the "funds following their own trades" part is significant for Basic Materials (mid market returns), Consumer Services (mid sector returns) and Technology (mid market returns and low sector returns). Regarding herding, the "funds following the trades of other funds" estimates exhibit significance during quarters of low market returns for Consumer Services, Financials and Industrials, during quarters of mid sector returns for Consumer Services and during quarters of low sector returns for Industrials. The significance of institutional herding in these sectors during quarters characterized mostly by low market/sector returns (i.e. relatively underperforming quarters) implies a relationship between market/sector performance and institutional industry herding, thus reflecting the latter's intentional nature. 
We now turn to assess the interaction between institutional industry herding and market/sector volatility, beginning from the impact over institutional industry herding of the relative change in the quarterly volatility of both the market index as well as the index of the sector under consideration. As table 5 illustrates, the Technology sector continues to maintain the significance of both its $\beta_{t^{-}}$ estimates and the "funds following the trades of other funds" estimates irrespective of whether the quarterly market/sector volatility has increased or decreased, again indicating that the demand of Spanish funds for Technology stocks is due to herding, which nevertheless produces no signs of intent. Aside from Technology, the significance of $\beta_{t}$ is manifested only for Industrials during quarters where sector volatility has decreased; the "funds following their own trades" part is significant only for Basic Materials (increased market volatility quarters) and Utilities (increased sector volatility quarters). The "funds following the trades of other funds" estimate is significant for Consumer Services (Industrials ${ }^{7}$ ) during increased (decreased) market and sector volatility quarters, indicating that institutional herding for these two sectors is intentional.

Table 6 presents the estimates from the break-up of $\beta_{t}$ and its two components into three parts (highmid-low market/sector volatility). The Technology sector retains the significance of both its $\beta_{t^{-}}$ estimates and the "funds following the trades of other funds" estimates in all tests performed, confirming once more that Spanish funds herd significantly in this sector. The significance of $\beta_{t}$ is evident during high market volatility quarters for the Industrials and Oil and Gas sectors and during high sector volatility quarters for Industrials. Regarding the "funds following their own trades" part, it appears significant for Oil and Gas during high market/sector volatility quarters and Technology (low sector volatility quarters). The picture emanating from the "funds following the trades of other funds" part indicates the presence of significant herding mostly during high market (Financials; Industrials) and sector (Consumer Services; Industrials) volatility quarters; it also appears significant during mid market (Basic Materials) and sector (Consumer Services) volatility quarters. The above indicate a relationship between institutional industry herding and market/sector volatility (herding is stronger when market/sector volatility is not low), confirming the presence of intentional herding.

\footnotetext{
${ }^{7}$ In the case of Industrials during decreased market volatility quarters, the sign of the "funds following the traders of other funds" part is negative, indicative of counter-herding.
} 
The interaction between institutional industry herding and market/sector volume is first illustrated controlling for the impact of the relative change in the quarterly volume of both the market index as well as the index of the sector under consideration over institutional industry herding. The relevant results are presented in table 7 , where again we notice the pattern of uniform significance for all tests of the $\beta_{t}$-estimates and the "funds following the trades of other funds" estimates for the Technology sector. Aside from Technology, $\beta_{t}$ exhibits significance only for Consumer Services during increasing market volume quarters. Evidence in favour of significant habit investing is witnessed for Oil and Gas (during quarters of decreasing market/sector volume), Industrials (decreasing sector volume quarters), Technology (decreasing sector volume quarters) and Utilities (increasing sector volume quarters). Regarding herding, the "funds following the trades of other funds" part appears significant for Consumer Services (during increasing market/sector volume quarters) and Industrials (decreasing sector volume quarters), indicating that institutional herding in these sectors is intentional.

Table 8 presents the estimates from the break-up of $\beta_{t}$ and its two components into three parts (highmid-low market/sector volume). Once more, Technology generates significant estimates for $\beta_{t}$ and the "funds following the trades of other funds" part. Evidence on the significance of $\beta_{t}$ is documented for Consumer Goods (low market volume quarters and high/mid sector volume quarters) and Consumer Services (high market/sector volume quarters). Most "funds following their own trades" estimates are insignificant with the exception of Consumer Goods for mid sector volume quarters and Oil and Gas (low sector volume quarters). Conversely, the "funds following the trades of other funds" estimates provide us with more evidence in favour of herding significance, in particular for Basic Materials (high market/sector volume quarters), Consumer Goods (high sector volume quarters), Consumer Services (high market/sector volume quarters), Financials (mid sector volume quarters) and Industrials (low sector volume quarters). The above results show that institutional industry herding tends to be stronger during quarters when trading activity is high, indicating that it is driven by intent.

Synthesizing our results from tables $3-8$, we see that institutional industry herding interacts significantly with market/sector returns, volatility and volume; these interactions exhibit regularities we consider worth noting: 
a) Underperformance: herding is significant during quarters of negative market returns (Financials; Industrials), negative sector returns (Consumer Services; Financials; Industrials), low market returns (Consumer Services; Financials; Industrials) and low sector returns (Industrials) with very little evidence of significance during other market/sector returns' states. Since periods of price-declines lead most investors to realize losses, "bad" managers would prefer to mimic their "good" peers during such periods in order to claim that, despite having made good investment choices (those they mimicked), they underperformed due to adverse market conditions.

b) Rising/high volatility: herding appears significant during quarters of increased market volatility (Consumer Services), increased sector volatility (Consumer Services), high market volatility (Financials; Industrials) and high sector volatility (Consumer Services; Industrials) with little evidence of significance during other market/sector volatility states. Volatile periods imply greater complexity which "bad" managers may find difficult to resolve due to their low processing skills, leading them to mimic their "good" peers instead.

c) Rising/high volume: herding appears significant during quarters of increased market/sector volume (Consumer Services), high market volume (Basic Materials; Consumer Services) and high sector volume (Basic Materials; Consumer Goods; Consumer Services) with little evidence of significance during other market/sector volume states. High volume reduces liquidity risk, thus encouraging informed investors (such as "good" managers) to trade on their information, increasing the visibility of their trades - and rendering it easier for "bad" managers to copy them.

Our findings therefore suggest that Spanish fund managers industry-herd intentionally, motivated primarily by informational and professional considerations. This is the case mainly with Consumer Services, Financials and Industrials and to a lesser extent for Basic Materials and Consumer Goods. Some sectors exhibited very little (Utilities) or no evidence (Healthcare; Oil and Gas) of herding significance when controlling for various market/sector conditions. Conversely, Technology presented us with overwhelming herding significance irrespective of the conditions tested, a fact possibly due to its stocks being perceived as riskier (most of them are of moderate size, often falling under the 
classification of growth stocks), thus prompting fund managers to copy their peers' trades when investing in them to minimize the perceived risk (see e.g. Wermers, 1999).

\section{Conclusion}

The present paper aims at investigating whether fund managers herd intentionally at the sector level and whether this intent is related to the specific conditions of each industry or whether the conditions of the market as a whole are also capable of promoting it. We examine the above drawing upon a unique database of quarterly portfolio holdings of Spanish mutual funds for the June 1995 September 2008 period. To gauge whether the observed herding in each sector is driven by intent or not we assess how it interacts with the performance (i.e. returns), volatility and volume of both that sector as well as the market as a whole. Our results indicate that Spanish fund managers herd significantly at the overall market level, while the interactions of their herding in each sector with these states reveal that fund managers herd significantly in a series of industries (this is the case mostly for Consumer Services, Financials and Industrials and to a lesser extent for Basic Materials and Consumer Goods) mainly during periods when the market as a whole or the specific sector under examination has underperformed, generated rising/high volatility and exhibited rising/high volume. These findings denote that Spanish fund managers herd in these sectors primarily motivated by informational and career-related reasons, consistent with the view that their herding is intentional.

Our results illustrate for the first time that institutional industry herding is intentional and that it is both market as well as sector conditions driving this intent. The above bear important implications for the investment community, particularly those investors engaged into sector styles, since being aware of the conditions that promote herding among funds investing in a sector can constitute a potentially useful input to their strategies. Our findings are also of interest to the regulatory authorities, as they provide them with novel insight into the versatile nature of intent underlying institutional industry herding which can help them when considering measures related to curtailing the incentives of fund managers to herd. 


\section{References}

Banerjee, A.V., 1992. A simple model of herd behavior. Quarterly Journal of Economics 107:3, 797817.

Bennett, J. R., Sias, R., Starks, L., 2003. Greener pastures and the impact of dynamic institutional preferences. Review of Financial Studies 16, 1203-1238.

Bikhchandani, S., Hirshleifer, D., Welch, I., 1992. A theory of fads, fashion, custom, and cultural change as informational cascades. Journal of Political Economy 100:5, 992-1026.

Bikhchandani S., Sharma, S., 2001. Herd behaviour in financial markets. IMF Staff Papers 47:3, 279310.

Chen, Y. F., Yang, S. Y., Lin, F. L., 2012. Foreign institutional industrial herding in Taiwan stock market. Managerial Finance 38:3, 325 - 340.

Choi, N., Sias, R.W., 2009. Institutional industry herding. Journal of Financial Economics 94, 469491.

Clement, M., Tse, S.Y., 2005. Financial analyst characteristics and herding behaviour in forecasting. Journal of Finance 60:1, 307-341.

De Bondt, W. F. M., Teh, L. L., 1997. Herding behavior and stock returns: an exploratory investigation. Swiss Journal of Economics and Statistics 133, 293-324.

Demirer, R., Kutan, A. M., 2006. Does herding behaviour exist in Chinese stock markets? Journal of International Financial Markets, Institutions and Money 16:2, 123-142.

Devenow, A., Welch, I., 1996. Rational herding in financial economics. European Economic Review 40:3-5, 603-615.

Economou, F., Kostakis, A., Philippas, N., 2011. Cross country effects in herding behaviour: Evidence from four South European Markets. Journal of International Financial Markets, Institutions and Money 21:3, 443-460.

Frazzini, A., Lamont O., 2008. Dumb money: mutual fund flows and the cross-section of stock returns, Journal of Financial Economics 88, 299-322.

Goodhart, C., Hartmann, P., Llewellyn, D., Rojas-Suarez, L., Weisbrod, S., 1999. Financial Regulation: Why, How And Where Now? Routledge: London. 
Hirshleifer, D., Teoh, S-H, 2003. Herd behaviour and cascading in capital markets: a review and synthesis. European Financial Management 9:1, 25-66.

Holmes, P.R., Kallinterakis, V., Leite Ferreira, M.P., 2011. Herding and window dressing in a concentrated market: a question of intent. European Financial Management, in press.

Kremer, S., Nautz, D., 2011. Short-term herding of institutional traders: new evidence from the german stock market. European Financial Management, in press.

Lakonishok, J., Shleifer, A., Vishny, R., 1992. The impact of institutional trading on stock prices. Journal of Financial Economics 32, 23-43.

Romano, M. G., 2007. Learning, cascades and transaction-costs. Review of Finance 11, 527-560.

Ross, S. A., 1989. Information and volatility: the no-arbitrage martingale approach to timing and resolution irrelevancy. The Journal of Finance 44:1, 1-17.

Scharfstein, D.S., Stein, J.C., 1990. Herd behaviour and investment. The American Economic Review $80: 3,465-479$.

Schwert G.W., 1989. Why does stock market volatility change over time. Journal of Finance 44:5, $1115-1553$.

Sias, R. W., 2004. Institutional herding. Review of Financial Studies 17, 165-206.

Trueman, B., 1994. Analyst forecasts and herding behaviour. Review of Financial Studies 7:1, 97124.

Voronkova, S., Bohl, M.T., 2005. Institutional traders' behaviour in an emerging stock market: empirical evidence on Polish pension fund investors. Journal of Business, Finance and Accounting $32: 7 \& 8,1537-1560$

Walter, A., Weber, M., 2006. Herding in the German mutual fund industry, European Financial Management 12, 375-406.

Wermers, R., 1999. Mutual fund herding and the impact on stock prices. Journal of Finance 54:2, 581622.

Wylie, S., 2005. Fund manager herding: a test of the accuracy of empirical results using U.K. data. Journal of Business 78:1, 381-403. 


\begin{tabular}{|c|c|c|c|c|c|c|c|c|c|c|c|c|c|c|c|}
\hline & $\begin{array}{c}\text { Total } \\
\text { Market }\end{array}$ & $\begin{array}{c}\text { Basic } \\
\text { Materials } \\
\end{array}$ & $\begin{array}{c}\text { Consumer } \\
\text { Goods }\end{array}$ & $\begin{array}{c}\text { Consumer } \\
\text { Services }\end{array}$ & Financials & Healthcare & Industrials & $\begin{array}{r}\text { Oil \& } \\
\text { Gas }\end{array}$ & Technology & Utilities & & & & & \\
\hline \multicolumn{16}{|l|}{ Panel A: Sample statistics } \\
\hline No. of Stocks & 245 & 23 & 33 & 28 & 65 & 10 & 54 & 6 & 6 & 20 & & & & & \\
\hline No. of Funds & 1543 & 1003 & 874 & 1189 & 4241 & 839 & 1176 & 1235 & 967 & 1409 & & & & & \\
\hline \multicolumn{16}{|l|}{ No. of Quarter- } \\
\hline holdings positions & 647045 & 36512 & 25472 & 75717 & 148810 & 12804 & 123648 & 41477 & 19394 & 151915 & & & & & \\
\hline No. of Stock-Quarters & 15190 & 1426 & 2046 & 1708 & 4030 & 620 & 3348 & 372 & 242 & 1240 & & & & & \\
\hline \multicolumn{16}{|l|}{ Panel B: Equity statistics } \\
\hline $\begin{array}{l}\text { Average number of active stocks } \\
\text { per quarter traded by at least one } \\
\text { fund }\end{array}$ & $\begin{array}{l}\text { Jun } 1995- \\
\text { Sep } 2008 \\
\end{array}$ & 1995 & 1996 & 1997 & 1998 & 1999 & 2000 & 2001 & 2002 & 2003 & 2004 & 2005 & 2006 & 2007 & 2008 \\
\hline Total Market & 79.9 & 36.8 & 40.6 & 66.8 & 82.1 & 100.1 & 94.2 & 81.5 & 81.3 & 77.3 & 85.3 & 94.8 & 96.1 & 98.0 & 83.2 \\
\hline Basic Materials & 15.6 & 15.7 & 15.5 & 16.3 & 18.5 & 18.5 & 17.0 & 17.0 & 15.5 & 14.8 & 14.3 & 14.3 & 13.8 & 14.0 & 14.0 \\
\hline Consumer Goods & 19.1 & 20.0 & 17.5 & 21.3 & 24.0 & 23.8 & 21.0 & 20.5 & 18.5 & 17.0 & 17.0 & 16.8 & 17.0 & 16.5 & 16.3 \\
\hline Consumer Services & 12.4 & 6.0 & 7.5 & 9.5 & 11.3 & 12.5 & 15.0 & 16.5 & 15.8 & 15.0 & 14.5 & 13.5 & 12.0 & 12.0 & 12.3 \\
\hline Financials & 34.2 & 30.7 & 33.0 & 33.3 & 37.3 & 38.0 & 34.3 & 34.0 & 33.8 & 33.5 & 33.0 & 31.0 & 33.3 & 37.5 & 36.3 \\
\hline Healthcare & 4.7 & 3.0 & 3.3 & 4.0 & 4.0 & 4.0 & 4.0 & 4.0 & 4.0 & 4.0 & 4.0 & 4.5 & 5.8 & 7.8 & 9.0 \\
\hline Industrials & 31.4 & 33.7 & 33.3 & 36.3 & 35.5 & 37.3 & 33.5 & 31.8 & 31.8 & 29.8 & 27.8 & 28.8 & 28.0 & 25.8 & 26.8 \\
\hline Oil \& Gas & 3.8 & 2.7 & 3.3 & 4.0 & 3.3 & 3.0 & 3.3 & 4.0 & 4.0 & 4.0 & 4.0 & 4.0 & 4.0 & 4.8 & 5.0 \\
\hline Technology & 3.5 & 1.3 & 1.0 & 1.0 & 1.8 & 3.5 & 5.0 & 5.0 & 4.8 & 4.5 & 5.0 & 4.8 & 4.0 & 4.0 & 4.0 \\
\hline Utilities & 11.3 & 14.0 & 14.5 & 14.5 & 15.0 & 14.5 & 9.0 & 8.5 & 9.0 & 9.0 & 9.0 & 9.0 & 9.5 & 10.3 & 11.8 \\
\hline \multicolumn{16}{|l|}{ Panel C: Funds' statistics } \\
\hline $\begin{array}{l}\text { Average No of active funds per } \\
\text { stock per quarter traded by } \geq 1 \text { fund }\end{array}$ & $\begin{array}{l}\text { Jun 1995- } \\
\text { Sep 2008 }\end{array}$ & 1995 & 1996 & 1997 & 1998 & 1999 & 2000 & 2001 & 2002 & 2003 & 2004 & 2005 & 2006 & 2007 & 2008 \\
\hline Total Market & 136.6 & 128.0 & 129.8 & 141.0 & 151.5 & 156.0 & 143.0 & 142.3 & 138.0 & 132.3 & 128.5 & 126.5 & 127.3 & 132.5 & 135.3 \\
\hline Basic Materials & 43.0 & 26.9 & 23.6 & 50.8 & 52.1 & 55.9 & 50.8 & 38.8 & 30.0 & 25.3 & 32.7 & 49.0 & 64.5 & 58.7 & 43.9 \\
\hline Consumer Goods & 25.9 & 14.2 & 14.4 & 27.2 & 32.0 & 33.4 & 25.4 & 21.5 & 20.9 & 21.3 & 24.9 & 32.9 & 32.4 & 34.1 & 28.0 \\
\hline Consumer Services & 113.6 & 54.9 & 53.7 & 114.5 & 123.4 & 156.7 & 139.6 & 107.6 & 103.7 & 110.2 & 130.2 & 150.5 & 135.3 & 119.5 & 90.7 \\
\hline Financials & 38.1 & 21.8 & 21.0 & 42.4 & 50.7 & 56.9 & 35.9 & 24.1 & 34.2 & 34.2 & 39.9 & 52.1 & 51.9 & 43.1 & 25.9 \\
\hline Healthcare & 40.3 & 2.7 & 3.1 & 19.9 & 31.2 & 32.7 & 64.4 & 64.0 & 56.3 & 45.9 & 40.6 & 35.6 & 42.2 & 65.0 & 61.2 \\
\hline Industrials & 46.2 & 37.0 & 36.8 & 48.7 & 69.7 & 82.0 & 46.2 & 25.1 & 28.8 & 29.0 & 33.8 & 48.8 & 56.6 & 55.4 & 48.2 \\
\hline Oil \& Gas & 182.2 & 71.5 & 81.1 & 116.6 & 161.8 & 269.6 & 198.5 & 221.2 & 197.5 & 195.3 & 210.1 & 233.6 & 229.8 & 189.3 & 175.7 \\
\hline Technology & 94.2 & 16.8 & 54.0 & 137.3 & 62.0 & 109.3 & 166.7 & 151.4 & 119.0 & 96.8 & 64.4 & 68.0 & 101.8 & 97.2 & 74.8 \\
\hline Utilities & 248.5 & 89.9 & 117.3 & 159.1 & 198.3 & 217.1 & 345.3 & 317.2 & 303.6 & 317.2 & 318.2 & 312.5 & 273.6 & 271.3 & 238.5 \\
\hline
\end{tabular}

Sample data include quarterly holdings of funds from Spain for the June 1995 - September 2008 period. For each quarter we calculate the number of stocks traded by at least one fund; for each quarter we also calculate both for the total market as well as for each sector separately. 


\section{Table 2: Tests for herding - Buyer if increased position}

\begin{tabular}{|c|c|c|c|c|}
\hline & $\begin{array}{c}\text { Average Coefficient } \\
(\beta)\end{array}$ & Funds following their own trades & $\begin{array}{l}\text { Funds following the } \\
\text { trades of other funds }\end{array}$ & Average $\mathrm{R}^{2}$ \\
\hline & 0.0426 & -0.0112 & 0.0538 & \\
\hline \multirow[t]{2}{*}{ All Sectors } & $(0.0206)$ & $(0.2005)$ & $(0.0001)$ & 0.0181 \\
\hline & 0.0017 & -0.0425 & 0.0442 & \\
\hline \multirow[t]{2}{*}{ Basic Materials } & $(0.9687)$ & $(0.0525)$ & $(0.2619)$ & 0.0987 \\
\hline & 0.0220 & -0.0484 & 0.0704 & \\
\hline \multirow[t]{2}{*}{ Consumer Goods } & $(0.5967)$ & $(0.2430)$ & $(0.1456)$ & 0.0867 \\
\hline & 0.1052 & -0.0439 & 0.1492 & \\
\hline \multirow[t]{2}{*}{ Consumer Services } & $(0.0658)$ & $(0.0694)$ & $(0.0045)$ & 0.1673 \\
\hline & 0.0376 & 0.0004 & 0.0372 & \\
\hline \multirow[t]{2}{*}{ Financials } & $(0.2466)$ & $(0.9820)$ & $(0.0612)$ & 0.0525 \\
\hline & 0.0324 & 0.0724 & -0.0400 & \\
\hline \multirow[t]{2}{*}{ Healthcare } & $(0.6894)$ & $(0.1416)$ & $(0.6113)$ & 0.3318 \\
\hline & 0.0572 & -0.0062 & 0.0634 & \\
\hline \multirow[t]{2}{*}{ Industrials } & $(0.0560)$ & $(0.6878)$ & $(0.0121)$ & 0.0463 \\
\hline & -0.0527 & -0.0021 & -0.0505 & \\
\hline \multirow[t]{2}{*}{ Oil \& Gas } & $(0.5697)$ & $(0.9446)$ & $(0.5813)$ & 0.4401 \\
\hline & 0.7775 & -0.1013 & 0.8788 & \\
\hline \multirow{2}{*}{ Technology } & $(0.0000)$ & $(0.0146)$ & $(0.0000)$ & 0.4275 \\
\hline & 0.0601 & 0.0105 & 0.0496 & \\
\hline Utilities & $(0.2755)$ & $(0.4736)$ & $(0.3559)$ & 0.1538 \\
\hline
\end{tabular}

This table reports the results for the following equation: $\Delta_{k, t}=\beta_{t} \Delta_{k, t-1}+\varepsilon_{k, t}$. For each security and quarter between June 1995 and September 2008 we calculate the fraction of funds that increase their position in the security in the Spanish market. A fund is defined as increasing its position if it holds a greater fraction of the firm's shares at the end of the quarter than it held at the beginning. All data are standardized (i.e. rescaled to zero mean, unit variance) each quarter. We then estimate quarterly cross-sectional regressions of institutional demand on lagged institutional demand. Because there is a single independent variable in each regression and the data are standardized, these regression coefficients are also the cross-sectional correlations between institutional demand and lagged institutional demand. The first column reports the time-series' averages of these 52 correlation coefficients and associated p-values (in parentheses) for the total market and each sector separately. The second and third columns report the portion of the correlation that results from funds following their own lagged trades and the portion that results from funds following the previous trades of other funds (herding) for the total market and each sector separately. 


\begin{tabular}{|c|c|c|c|c|c|c|c|c|c|c|c|c|c|c|c|c|}
\hline \multicolumn{9}{|c|}{ Panel A: Market Returns Split } & \multicolumn{8}{|c|}{ Panel B: Sector Returns Split } \\
\hline & \multicolumn{2}{|c|}{$\begin{array}{c}\text { Average Coefficient } \\
(\beta)\end{array}$} & \multicolumn{2}{|c|}{$\begin{array}{l}\text { Funds following } \\
\text { their own trades }\end{array}$} & \multicolumn{2}{|c|}{$\begin{array}{l}\text { Funds following the } \\
\text { trades of other funds }\end{array}$} & \multicolumn{2}{|c|}{ Average $\mathrm{R}^{2}$} & \multicolumn{2}{|c|}{$\begin{array}{c}\text { Average Coefficient } \\
(\beta)\end{array}$} & \multicolumn{2}{|c|}{$\begin{array}{l}\text { Funds following } \\
\text { their own trades }\end{array}$} & \multicolumn{2}{|c|}{$\begin{array}{l}\text { Funds following the } \\
\text { trades of other funds }\end{array}$} & \multicolumn{2}{|c|}{ Average $\mathrm{R}^{2}$} \\
\hline & Positive & Negative & Positive & Negative & Positive & Negative & Positive & Negative & Positive & Negative & Positive & Negative & Positive & Negative & Positive & Negative \\
\hline Basic & -0.0401 & 0.0687 & -0.0580 & -0.0177 & 0.0179 & 0.0864 & & & -0.0231 & 0.0450 & -0.0471 & -0.0346 & 0.0240 & 0.0796 & & \\
\hline Materials & $(0.5065)$ & $(0.3055)$ & $(0.0751)$ & $(0.4622)$ & $(0.7080)$ & $(0.2178)$ & 0.1028 & 0.0877 & $(0.7080)$ & $(0.4708)$ & $(0.1434)$ & $(0.1427)$ & $(0.6201)$ & $(0.2576)$ & 0.1132 & 0.0689 \\
\hline Consumer & 0.0537 & -0.0287 & -0.0533 & -0.0404 & 0.1070 & 0.0118 & & & -0.0033 & 0.0455 & -0.0878 & -0.0120 & 0.0845 & 0.0575 & & \\
\hline Goods & $(0.2976)$ & $(0.6924)$ & $(0.4133)$ & $(0.1948)$ & $(0.1350)$ & $(0.8267)$ & 0.0810 & 0.0960 & $(0.9482)$ & $(0.4942)$ & $(0.2746)$ & $(0.7045)$ & $(0.3440)$ & $(0.2136)$ & 0.0592 & 0.1123 \\
\hline Consumer & 0.1478 & 0.0371 & -0.0198 & -0.0825 & 0.1676 & 0.1196 & & & 0.0666 & 0.1540 & -0.0462 & -0.0411 & 0.1128 & 0.1951 & & \\
\hline \multirow[t]{2}{*}{ Services } & $(0.0605)$ & $(0.6490)$ & $(0.4023)$ & $(0.1063)$ & $(0.0259)$ & $(0.0840)$ & 0.1908 & 0.1299 & $(0.4250)$ & $(0.0475)$ & $(0.2288)$ & $(0.1296)$ & $(0.1263)$ & $(0.0112)$ & 0.1887 & 0.1405 \\
\hline & -0.00716 & 0.1094 & -0.0237 & 0.0392 & 0.0166 & 0.0702 & & & -0.0142 & 0.1207 & -0.0337 & 0.0550 & 0.0194 & 0.0657 & & \\
\hline Financials & $\begin{array}{l}(0.8628) \\
-0.0021\end{array}$ & $\begin{array}{c}(0.0369) \\
0.0878\end{array}$ & $\begin{array}{c}(0.3359) \\
0.0964\end{array}$ & $\begin{array}{c}(0.2342) \\
0.0341\end{array}$ & $\begin{array}{l}(0.5258) \\
-0.0986\end{array}$ & $\begin{array}{c}(0.0224) \\
0.0537\end{array}$ & 0.0499 & 0.0567 & $\begin{array}{c}(0 . / 2 / 4) \\
0.0390\end{array}$ & $\begin{array}{c}(0.0224) \\
0.0210\end{array}$ & $\begin{array}{c}(0.1665) \\
0.0773\end{array}$ & $\begin{array}{c}(0.0922) \\
0.0641\end{array}$ & $\begin{array}{l}(0.4782) \\
-0.0383\end{array}$ & $\begin{array}{l}(0.0191) \\
-0.0430\end{array}$ & 0.0491 & 0.0581 \\
\hline \multirow[t]{2}{*}{ Healthcare } & $(0.9840)$ & $(0.4708)$ & $(0.1842)$ & $(0.5512)$ & $(0.3485)$ & $(0.6546)$ & 0.3651 & 0.3319 & $(0.7169)$ & $(0.8674)$ & $(0.2601)$ & $(0.3379)$ & $(0.6875)$ & $(0.7647)$ & 0.3618 & 0.2799 \\
\hline & 0.0403 & 0.0841 & -0.0004 & -0.0154 & 0.0408 & 0.0995 & & & 0.0341 & 0.0974 & 0.0021 & -0.0206 & 0.0320 & 0.1179 & & \\
\hline \multirow[t]{2}{*}{ Industrials } & $(0.3200)$ & $(0.0586)$ & $(0.9832)$ & $(0.4785)$ & $(0.2461)$ & $(0.0040)$ & 0.0517 & 0.0379 & $(0.3717)$ & $(0.0490)$ & $(0.9219)$ & $(0.3627)$ & $(0.3218)$ & $(0.0034)$ & 0.0461 & 0.0469 \\
\hline & 0.0839 & -0.2714 & 0.0169 & -0.0328 & 0.0669 & -0.2386 & & & 0.0039 & -0.1511 & 0.0169 & -0.0352 & -0.0129 & -0.1159 & & \\
\hline \multirow[t]{2}{*}{ Oil \& Gas } & $(0.5030)$ & $(0.0397)$ & $(0.7371)$ & $(0.0140)$ & $(0.5952)$ & $(0.0601)$ & 0.4885 & 0.3627 & $(0.9734)$ & $(0.3308)$ & $(0.7287)$ & $(0.0479)$ & $(0.9136)$ & $(0.4320)$ & 0.4417 & 0.4373 \\
\hline & 0.8350 & 0.6962 & -0.0908 & -0.1162 & 0.9258 & 0.8125 & & & 0.9857 & 0.5978 & -0.0724 & -0.1264 & 1.0581 & 0.7241 & & \\
\hline \multirow[t]{2}{*}{ Technology } & $(0.0002)$ & $(0.0047)$ & $(0.0630)$ & $(0.1233)$ & $(0.0001)$ & $(0.0056)$ & 0.4068 & 0.4569 & $(0.0004)$ & $(0.0020)$ & $(0.1742)$ & $(0.0473)$ & $(0.0004)$ & $(0.001)$ & 0.4341 & 0.4079 \\
\hline & 0.0232 & 0.1193 & 0.0160 & 0.0017 & 0.0071 & 0.1175 & & & 0.0752 & 0.0342 & 0.0133 & 0.0058 & 0.0618 & 0.0285 & & \\
\hline Utilities & $(0.7325)$ & $(0.2150)$ & $(0.4324)$ & $(0.9321)$ & $(0.9185)$ & $(0.1679)$ & 0.1295 & 0.1928 & $(0.2834)$ & $(0.7137)$ & $(0.5038)$ & $(0.7910)$ & $(0.3930)$ & $(0.7226)$ & 0.1459 & 0.1676 \\
\hline $\begin{array}{l}\text { and the } \\
\text { groups, c } \\
\text { returns, } \\
\text { first colu }\end{array}$ & -5 & t & 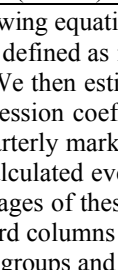 & 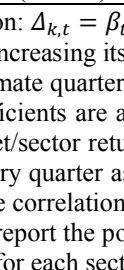 & -5 & -5 & 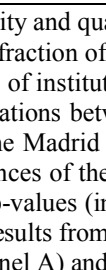 & 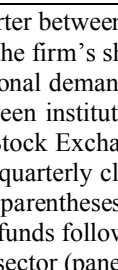 & 2 & 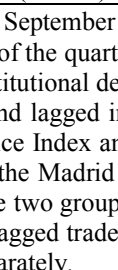 & $2=$ & $4=$ & 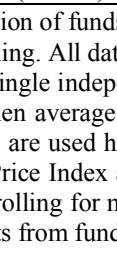 & 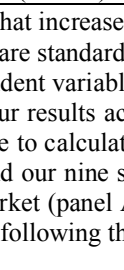 & eir 1 & $\begin{array}{l}\text { ession } \\
\text { nctive } \\
\text { sector } \\
\text {. The } \\
\text { panel } \\
\text { des of }\end{array}$ \\
\hline
\end{tabular}




\begin{tabular}{|c|c|c|c|c|c|c|c|c|c|c|c|c|}
\hline & \multicolumn{3}{|c|}{$\begin{array}{l}\text { Average Coefficient } \\
(\beta)\end{array}$} & \multicolumn{3}{|c|}{ Funds following their own trades } & \multicolumn{3}{|c|}{$\begin{array}{l}\text { Funds following the } \\
\text { trades of other funds }\end{array}$} & \multicolumn{3}{|c|}{ Average $\mathrm{R}^{2}$} \\
\hline & High & Mid & Low & High & Mid & Low & High & Mid & Low & High & Mid & Low \\
\hline \multicolumn{13}{|c|}{ Panel A: Market Returns } \\
\hline Basic & 0.0044 & -0.0380 & 0.0411 & -0.0246 & -0.1003 & 0.0008 & 0.0291 & 0.0622 & 0.0403 & & & \\
\hline Materials & $(0.9648)$ & $(0.5369)$ & $(0.5730)$ & $(0.5732)$ & $(0.0255)$ & $(0.9668)$ & $(0.7101)$ & $(0.3456)$ & $(0.5445)$ & 0.1470 & 0.0601 & 0.0861 \\
\hline Consumer & 0.0359 & 0.1010 & -0.0754 & 0.0153 & -0.1096 & -0.0473 & 0.0206 & 0.2106 & -0.0281 & & & \\
\hline Goods & $(0.6281)$ & $(0.1457)$ & $(0.3231)$ & $(0.7218)$ & $(0.3246)$ & $(0.1440)$ & $(0.6550)$ & $(0.0851)$ & $(0.6211)$ & 0.0835 & 1.1022 & 0.0938 \\
\hline Consumer & 0.0547 & 0.0511 & 0.2131 & -0.0921 & -0.0131 & -0.0283 & 0.1468 & 0.0642 & 0.2415 & & & \\
\hline \multirow[t]{2}{*}{ Services } & $(0.6459)$ & $(0.4994)$ & $(0.0454)$ & $(0.1732)$ & $(0.1904)$ & $(0.3762)$ & $(0.1812)$ & $(0.1812)$ & $(0.0112)$ & 0.2244 & 0.1008 & 0.1810 \\
\hline & -0.0213 & 0.0359 & 0.0984 & -0.0262 & -0.0047 & 0.0326 & 0.0049 & 0.0407 & 0.0658 & & & \\
\hline \multirow[t]{2}{*}{ Financials } & $(0.7271)$ & $(0.5332)$ & $(0.0630)$ & $(0.4400)$ & $(0.8971)$ & $(0.3301)$ & $(0.8953)$ & $(0.2402)$ & $(0.0481)$ & 0.0559 & 0.0519 & 0.0497 \\
\hline & -0.0557 & 0.0434 & 0.1089 & 0.1061 & 0.0586 & 0.0534 & -0.1619 & -0.0151 & 0.0555 & & & \\
\hline \multirow[t]{2}{*}{ Healthcare } & $(0.7441)$ & $(0.7106)$ & $(0.4480)$ & $(0.3623)$ & $(0.4498)$ & $(0.3862)$ & $(0.2915)$ & $(0.9035)$ & $(0.6931)$ & 0.4458 & 0.2299 & 0.3260 \\
\hline & 0.0734 & 0.0200 & 0.0803 & 0.0062 & -0.0109 & -0.0136 & 0.0672 & 0.0309 & 0.0093 & & & \\
\hline \multirow[t]{2}{*}{ Industrials } & $(0.1816)$ & $(0.7071)$ & $(0.1168)$ & $(0.8604)$ & $(0.5960)$ & $(0.5924)$ & $(0.1195)$ & $(0.5397)$ & $(0.0166)$ & 0.0517 & 0.0459 & 0.0416 \\
\hline & 0.0345 & 0.0258 & -0.2231 & 0.0659 & -0.0425 & -0.0276 & -0.0314 & 0.0683 & -0.1955 & & & \\
\hline \multirow[t]{2}{*}{ Oil \& Gas } & $(0.8403)$ & $(0.8809)$ & $(0.1276)$ & $(0.4797)$ & $(0.0747)$ & $(0.0520)$ & $(0.8546)$ & $(0.6894)$ & $(0.1684)$ & 0.4430 & 0.5114 & 0.3617 \\
\hline & 0.9726 & 0.8415 & 0.5085 & -0.0227 & -0.1673 & -0.1038 & 0.9953 & 1.0089 & 0.6123 & & & \\
\hline \multirow[t]{2}{*}{ Technology } & $(0.0066)$ & $(0.0093)$ & $(0.0000)$ & $(0.5870)$ & $(0.0286)$ & $(0.2584)$ & $(0.0077)$ & $(0.0059)$ & $(0.0009)$ & 0.4145 & 0.4752 & 0.3857 \\
\hline & 0.0229 & 0.0571 & 0.1006 & 0.0093 & 0.0265 & -0.0051 & 0.0136 & 0.0305 & 0.1057 & & & \\
\hline Utilities & $(0.8240)$ & $(0.4971)$ & $(0.3499)$ & $(0.7825)$ & $(0.2249)$ & $(0.8130)$ & $(0.9005)$ & $(0.7024)$ & $(0.2761)$ & 0.1362 & 0.1232 & 0.2039 \\
\hline \multicolumn{13}{|c|}{ Panel B: Sector Returns } \\
\hline Basic & -0.0665 & 0.0559 & 0.0127 & -0.0489 & -0.0534 & -0.0247 & -0.0176 & 0.1092 & 0.0374 & & & \\
\hline Materials & $(0.4696)$ & $(0.4929)$ & $(0.8381)$ & $(0.3180)$ & $(0.2060)$ & $(0.2006)$ & $(0.8275)$ & $(0.0982)$ & $(0.5454)$ & 0.1228 & 0.1077 & 0.0600 \\
\hline Consumer & 0.0213 & 0.0088 & 0.0369 & -0.1169 & -0.0267 & -0.0029 & 0.1382 & 0.0355 & 0.0398 & & & \\
\hline Goods & $(0.7605)$ & $(0.8902)$ & $(0.6777)$ & $(0.3212)$ & $(0.4262)$ & $(0.9452)$ & $(0.2899)$ & $(0.3973)$ & $(0.5348)$ & 0.0768 & 0.0674 & 0.1172 \\
\hline Consumer & 0.0604 & 0.1506 & 0.1022 & -0.0411 & -0.0733 & -0.0157 & 0.1015 & 0.2239 & 0.1178 & & & \\
\hline \multirow[t]{2}{*}{ Services } & $(0.6039)$ & $(0.1016)$ & $(0.2918)$ & $(0.5129)$ & $(0.0270)$ & $(0.5185)$ & $(0.2689)$ & $(0.0229)$ & $(0.1899)$ & 0.1909 & 0.1718 & 0.1391 \\
\hline & -0.0189 & 0.0520 & 0.0823 & -0.0178 & -0.0172 & 0.0448 & -0.0011 & 0.0691 & 0.0375 & & & \\
\hline \multirow{2}{*}{ Financials } & $(0.7551)$ & $(0.3807)$ & $(0.1512)$ & $(0.5932)$ & $(0.6495)$ & $(0.2318)$ & $(0.9779)$ & $(0.0664)$ & $(0.1701)$ & 0.0541 & 0.0518 & 0.0517 \\
\hline & -0.0033 & 0.0494 & 0.0503 & 0.1298 & 0.0598 & 0.0285 & -0.1331 & -0.0104 & 0.0218 & & & \\
\hline \multirow[t]{2}{*}{ Healthcare } & $(0.9833)$ & $(0.7364)$ & (0.6977) & $(0.3242)$ & $(0.2425)$ & $(0.6417)$ & $(0.3461)$ & $(0.9442)$ & $(0.8646)$ & 0.3779 & 0.3535 & 0.2630 \\
\hline & 0.0332 & 0.0495 & 0.0893 & 0.0236 & -0.0132 & -0.02879 & 0.0096 & 0.0627 & 0.1180 & & & \\
\hline \multirow{2}{*}{ Industrials } & $(0.5825)$ & $(0.2783)$ & $(0.0953)$ & $(0.4867)$ & $(0.5579)$ & $(0.2449)$ & $(0.8514)$ & $(0.0948)$ & $(0.0074)$ & 0.0557 & 0.0354 & 0.0487 \\
\hline & 0.0639 & -0.0663 & -0.1550 & 0.0656 & -0.0321 & -0.0383 & -0.0017 & -0.0343 & -0.1167 & & & \\
\hline \multirow[t]{2}{*}{ Oil \& Gas } & $(0.7274)$ & $(0.6672)$ & $(0.3223)$ & $(0.4849)$ & $(0.0630)$ & $(0.0544)$ & $(0.9926)$ & $(0.8277)$ & $(0.4270)$ & 0.5254 & 0.4015 & 0.3957 \\
\hline & 0.9419 & 0.6935 & 0.7101 & -0.0359 & -0.0726 & -0.2000 & 0.9778 & 0.7661 & 0.9101 & & & \\
\hline \multirow{2}{*}{ Technology } & $(0.0084)$ & $(0.0007)$ & $(0.0279)$ & $(0.3902)$ & $(0.3320)$ & $(0.0309)$ & $(0.0088)$ & $(0.0012)$ & $(0.0167)$ & 0.3886 & 0.4635 & 0.4250 \\
\hline & 0.0627 & 0.0804 & 0.0363 & 0.0164 & 0.0106 & 0.0047 & 0.0463 & 0.0698 & 0.0316 & & & \\
\hline Utilities & $(0.5698)$ & $(0.3162)$ & $(0.7280)$ & $(0.5854)$ & $(0.6632)$ & $(0.8467)$ & $(0.6925)$ & $(0.3765)$ & $(0.7243)$ & 0.1601 & 0.1168 & 0.1866 \\
\hline
\end{tabular}

This table reports the results for the following equation: $\Delta_{k, t}=\beta_{t} \Delta_{k, t-1}+\varepsilon_{k, t}$. For each security and quarter between June 1995 and September 2008 we calculate the fraction of funds that increase their position in the security in the Spanish market. A fund is defined as increasing its position if it holds a greater fraction of the firm's shares at the end of the quarter than it held at the beginning. All data are standardized (i.e. rescaled to zero mean, unit variance) each quarter. We then estimate quarterly cross-sectional regressions of institutional demand on lagged institutional demand. Because there is a single independent variable in each regression and the data are standardized, these regression coefficients are also the cross-sectional correlations between institutional demand and lagged institutional demand. We then average our results across three distinctive groups, namely "high", "mid" and "low" contingent upon whether the market's/sector's return during the contemporaneous quarter falls in the top, middle or bottom third of the sample period's quarterly market/sector return-values ranked in ascending order. Returns here are calculated as the first logarithmic differences of the quarterly closing prices of the Madrid Stock Exchange General Price Index and our nine sectors' indices. The first column reports the time-series' average of these correlation coefficients and associated p-values (in parentheses) for each of the three groups and for each sector, controlling for market (panel A) and sector (panel B) returns separately. The second and third columns report the portion of the correlation that results from funds following their own lagged trades and the portion that results from funds following the previous trades of other funds (herding) for each of the three groups and for each sector, controlling for market (panel A) and sector (panel B) returns separately. 
Table 5 - Tests for herding - controlling for market and sector volatility (Positive-Negative)

\begin{tabular}{|c|c|c|c|c|c|c|c|c|c|c|c|c|c|c|c|c|}
\hline \multicolumn{9}{|c|}{ Panel A: Market Volatility Split } & \multicolumn{8}{|c|}{ Panel B: Sector Volatility Split } \\
\hline & \multicolumn{2}{|c|}{$\begin{array}{c}\text { Average Coefficient } \\
(\beta)\end{array}$} & \multicolumn{2}{|c|}{$\begin{array}{c}\text { Funds following their } \\
\text { own trades }\end{array}$} & \multicolumn{2}{|c|}{$\begin{array}{l}\text { Funds following the } \\
\text { trades of other funds }\end{array}$} & \multicolumn{2}{|c|}{ Average $\mathrm{R}^{2}$} & \multicolumn{2}{|c|}{$\begin{array}{c}\text { Average Coefficient } \\
(\beta)\end{array}$} & \multicolumn{2}{|c|}{$\begin{array}{c}\text { Funds following their } \\
\text { own trades }\end{array}$} & \multicolumn{2}{|c|}{$\begin{array}{l}\text { Funds following the } \\
\text { trades of other funds }\end{array}$} & \multicolumn{2}{|c|}{ Average $\mathrm{R}^{2}$} \\
\hline & Increased & Decreased & Increased & Decreased & Increased & Decreased & Increased & Decreased & Increased & Decreased & Increased & Decreased & Increased & Decreased & Increased & Decreased \\
\hline Basic & 0.00 & 0.0016 & -0.0812 & & 0.0830 & & & & -0.0698 & & 0.0404 & 0.0479 & 0.0404 & 0.0479 & & \\
\hline Materials & $(0.9740)$ & $(0.9810)$ & $(0.0149)$ & $(0.8160)$ & $(0.1472)$ & $(0.8803)$ & 0.0751 & 0.1060 & $(0.0515)$ & $(0.5165)$ & $(0.4811)$ & $(0.3926)$ & $(0.4811)$ & $(0.3926)$ & 0.0869 & 0.1064 \\
\hline Consumer & 0.0524 & -0.0060 & -0.1003 & -0.0003 & 0.1527 & -0.0057 & & & 0.0693 & -0.0099 & -0.0974 & -0.0152 & 0.1667 & 0.0053 & & \\
\hline Goods & $(0.4123)$ & $(0.9132)$ & $(0.2147)$ & $(0.9905)$ & $(0.0936)$ & $(0.8869)$ & 0.0987 & 0.0757 & $(0.3619)$ & $(0.8388)$ & $(0.3223)$ & $(0.5171)$ & $(0.1150)$ & $(0.8925)$ & 0.1140 & 0.0683 \\
\hline Consumer & 0.1382 & 0.0747 & -0.0826 & -0.0080 & 0.2209 & 0.0827 & & & 0.1472 & 0.0564 & -0.0717 & -0.0116 & 0.2188 & 0.0680 & & \\
\hline \multirow[t]{2}{*}{ Services } & $(0.0939)$ & $(0.3589)$ & $(0.0747)$ & $(0.6633)$ & $(0.0029)$ & $(0.2735)$ & 0.1725 & 0.1627 & $(0.1017)$ & $(0.4111)$ & $(0.0833)$ & $(0.5854)$ & $(0.0080)$ & $(0.2767)$ & 0.2041 & 46 \\
\hline & 0.0656 & 0.0118 & 0.0195 & -0.0172 & 0.0460 & 0.0291 & & & 0.0848 & 0.0003 & 0.0331 & -0.0254 & 0.0518 & 0.0257 & & \\
\hline \multirow[t]{2}{*}{ Financials } & (0.1907) & $(0.7840)$ & $(0.5256)$ & $(0.5014)$ & $(0.1110)$ & $(0.3021)$ & 0.0601 & 0.0455 & $(0.1270)$ & $(0.9)$ & $(0.2943)$ & $(0.3146)$ & (0.1119) & $(0.3095)$ & 0.0688 & 0.0396 \\
\hline & 0.0779 & -0.0096 & 0.0787 & 0.0666 & -0.0007 & -0.0763 & & & 0.0419 & 0.023 & 0.0751 & 0.0698 & -0.0333 & -0.0467 & & \\
\hline \multirow[t]{2}{*}{ Healthcare } & $(0.5213)$ & $(0.9308)$ & $(0.3865)$ & $(0.1573)$ & $(0.9947)$ & $(0.5098)$ & 0.3504 & 0.3147 & $(0.7087)$ & $(0.8489)$ & $(0.3651)$ & $(0.2130)$ & $(0.7579)$ & $(0.6917)$ & 0.3084 & 0.3554 \\
\hline & 0.0459 & -0.0100 & 0.0075 & 0.0133 & 0.1284 & -0.0233 & & & 0.0214 & 0.0930 & -0.0250 & 0.0126 & 0.0464 & 0.0804 & & \\
\hline \multirow[t]{2}{*}{ Industrials } & $(0.3631)$ & $(0.0543)$ & $(0.3700)$ & $(0.8079)$ & $(0.1272)$ & $(0.0378)$ & 0.0613 & 0.0326 & $(0.6331)$ & $(0.0211)$ & $(0.2121)$ & $(0.5975)$ & $(0.2006)$ & $(0.0261)$ & 0.0472 & 0.0456 \\
\hline & 0.0176 & -0.1179 & 0.0121 & -0.0153 & 0.0055 & -0.1025 & & & 0.0333 & -0.1264 & -0.0417 & 0.0317 & 0.0750 & -0.1582 & & \\
\hline \multirow[t]{2}{*}{ Oil \& Gas } & $(0.8837)$ & $(0.4068)$ & $(0.8512)$ & $(0.2604)$ & $(0.9650)$ & $(0.4481)$ & 0.3508 & 0.5228 & $(0.8064)$ & $(0.3295)$ & $(0.0594)$ & $(0.5667)$ & $(0.5667)$ & $(0.2222)$ & 0.4144 & 0.4622 \\
\hline & 0.9125 & 0.6297 & -0.1020 & -0.1059 & 1.0145 & 0.7357 & & & 0.5600 & 0.8670 & -0.0996 & -0.1074 & 0.6596 & 0.9744 & & \\
\hline \multirow[t]{2}{*}{ Technology } & $(0.0047)$ & $(0.0013)$ & $(0.1739)$ & $(0.0819)$ & $(0.0060)$ & $(0.0006)$ & 0.4069 & 0.4052 & $(0.0102)$ & $(0.0006)$ & $(0.1672)$ & $(0.0848)$ & $(0.0092)$ & $(0.0005)$ & 0.3339 & 0.4518 \\
\hline & 0.1360 & -0.1528 & 0.4544 & 0.5582 & 1.5786 & -0.3435 & & & 0.0258 & 0.7159 & 0.0126 & 0.4701 & 0.0132 & 0.8428 & & \\
\hline Utilities & $(0.1334)$ & $(0.8798)$ & $(0.6536)$ & $(0.5815)$ & $(0.1275)$ & $(0.7340)$ & 0.1898 & 0.1205 & $(0.0974)$ & $(0.2666)$ & $(0.0084)$ & $(0.7352)$ & $(0.0890)$ & $(0.3091)$ & 0.1357 & 0.1734 \\
\hline
\end{tabular}

This table reports the results for the following equation: $\Delta_{k, t}=\beta_{t} \Delta_{k, t-1}+\varepsilon_{k, t}$. For each security and quarter between June 1995 and September 2008 we calculate the fraction of funds that increase their position in the security in the Spanish market. A fund is defined as increasing its position if it holds a greater fraction of the firm's shares at the end of the quarter than it held at the beginning. All data are standardized (i.e. rescaled to zero mean, unit variance) each quarter. We then estimate quarterly cross-sectional regressions of institutional demand on lagged institutional demand. Because there is a single independent variable in each regression and the data are standardized, these regression coefficients are also the cross-sectional correlations between institutional demand and lagged institutional demand. We then average our results across two distinctive groups, contingent upon whether the quarterly market/sector volatility has increased or decreased. The Madrid Stock Exchange General Price Index and our nine sectors' indices are used here to calculate market and sector returns, respectively. Market/sector volatility here is calculated every quarter using the standard deviation of daily index returns in quarterly intervals in line with Schwert (1989) on the basis of the Madrid Stock Exchange General Price Index and our nine sectors' indices. The first column reports the time-series' averages of these correlation coefficients and associated p-values (in parentheses) for each of the two groups and for each sector, controlling for market (panel A) and sector (panel B) volatility separately. The second and third columns report the portion of the correlation that results from funds following their own lagged trades and the portion that results from funds following the previous trades of other funds (herding) for each of the two groups and for each sector, controlling for market (panel A) and sector (panel B) volatility separately. 


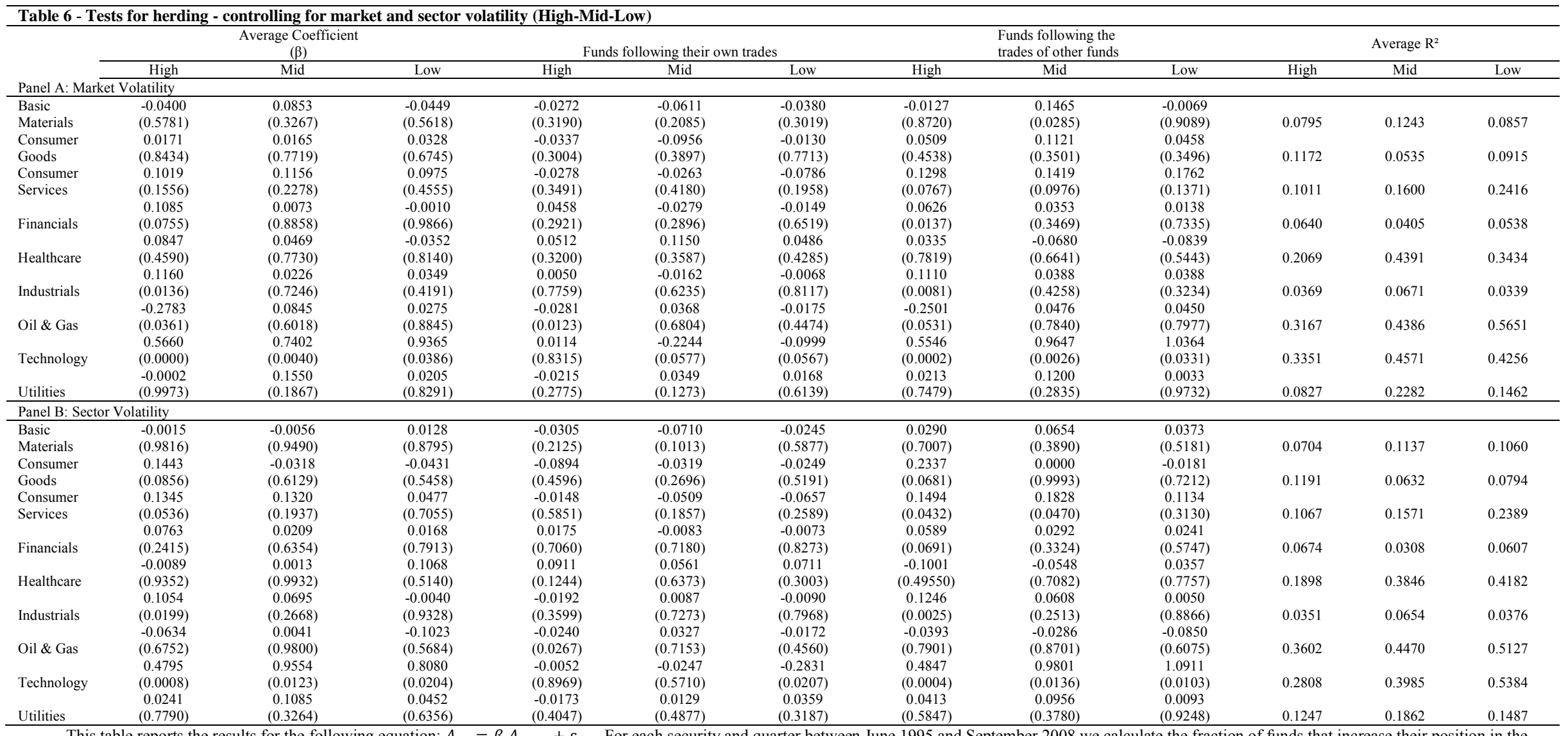

This table reports the results for the following equation: $\Delta_{k, t}=\beta_{t} \Delta_{k, t-1}+\varepsilon_{k, t}$. For each security and quarter between June 1995 and September 2008 we calculate the fraction of funds that increase their position in the security in the Spanish market. A fund is defined as increasing its position if it holds a greater fraction of the firm's shares at the end of the quarter than it held at the beginning. All data are standardized (i.e. rescaled to zero mean, unit variance) each quarter. We then estimate quarterly cross-sectional regressions of institutional demand on lagged institutional demand. Because there is a single independent variable in each regression and the data are standardized, these regression coefficients are also the cross-sectional correlations between institutional demand and lagged institutional demand. We then average our results across three distinctive groups, namely "high", "mid" and "low" contingent upon whether the market's/sector's volatility during the contemporaneous quarter falls in the top, middle or bottom third of the sample period's quarterly market/sector volatility-values ranked in ascending order. Market/sector volatility here is calculated every quarter using the standard deviation of daily index returns in quarterly intervals in line with Schwert (1989) on the basis of the Madrid Stock Exchange General Price Index and our nine sectors' indices. The first column reports the time-series' average of these correlation coefficients and associated p-values (in parentheses) for each of the three groups and for each sector, controlling for market (panel A) and sector (panel B) volatility separately. The second and third columns report the portion of the correlation that results from funds following their own lagged trades and the portion that results from funds following the previous trades of other funds (herding) for each of the three groups and for each sector, controlling for market (panel A) and sector (panel B) volatility separately. 


\begin{tabular}{|c|c|c|c|c|c|c|c|c|c|c|c|c|c|c|c|c|}
\hline \multicolumn{9}{|c|}{ Panel A: Market Volume Split } & \multicolumn{8}{|c|}{ Panel B: Sector Volume Split } \\
\hline & \multicolumn{2}{|c|}{$\begin{array}{c}\text { Average Coefficient } \\
(\beta)\end{array}$} & \multicolumn{2}{|c|}{$\begin{array}{c}\text { Funds following their } \\
\text { own trades }\end{array}$} & \multicolumn{2}{|c|}{$\begin{array}{l}\text { Funds following the } \\
\text { trades of other funds }\end{array}$} & \multicolumn{2}{|c|}{ Average $\mathrm{R}^{2}$} & \multicolumn{2}{|c|}{$\begin{array}{c}\text { Average Coefficient } \\
(\beta)\end{array}$} & \multicolumn{2}{|c|}{$\begin{array}{l}\text { Funds following their } \\
\text { own trades }\end{array}$} & \multicolumn{2}{|c|}{$\begin{array}{l}\text { Funds following the } \\
\text { trades of other funds }\end{array}$} & \multicolumn{2}{|c|}{ Average $\mathrm{R}^{2}$} \\
\hline & Increased & Decreased & Increased & Decreased & Increased & Decreased & Increased & Decreased & Increased & Decreased & Increased & Decreased & Increased & Decreased & Increased & Decreased \\
\hline Basic Materials & $\begin{array}{c}-0.0435 \\
(0.4732)\end{array}$ & $\begin{array}{c}0.0635 \\
(0.3471)\end{array}$ & $\begin{array}{l}-0.0489 \\
(0.1062)\end{array}$ & $\begin{array}{l}-0.0338 \\
(0.2989)\end{array}$ & $\begin{array}{c}0.0053 \\
(0.9172)\end{array}$ & $\begin{array}{c}0.0973 \\
(0.1201)\end{array}$ & 0.1002 & 0926 & $\begin{array}{c}-0.0309 \\
(0.6976)\end{array}$ & $\begin{array}{c}0.0297 \\
(0.5522)\end{array}$ & $\begin{array}{l}-0.0545 \\
(0.1508)\end{array}$ & $\begin{array}{c}-0.0323 \\
(0.2061)\end{array}$ & $\begin{array}{c}0.0236 \\
(0.7131)\end{array}$ & $\begin{array}{c}0.0620 \\
(0.2156)\end{array}$ & 0.1344 & 0.0650 \\
\hline Consumer & 0.0539 & & & & 0.1146 & 0.0102 & & & 0.0840 & -0.0270 & -0.0612 & & 0.1452 & & & \\
\hline Goods & $(0.3494)$ & $(0$ & $(0$ & $(0$ & $(0.1316)$ & $(0.83$ & 0.0955 & 0.0748 & $(0.2469)$ & $(0.5781)$ & $(0.4995)$ & $(0.1087)$ & $(0.1453)$ & $(0.7649)$ & 0.1145 & 0.0648 \\
\hline Consumer & 0.1825 & -0.0001 & -0 & -0 . & 0.1971 & 0.0838 & & & 0.1126 & 0.0945 & -0.0555 & -0.0269 & 0.1681 & 0.1214 & & \\
\hline Services & $(0.0135)$ & 985) & 49) & $(0$. & $(0.0075)$ & $(0.2680)$ & 0.1524 & 0.1879 & $(0.1266)$ & $(0.3155)$ & $(0.1119)$ & $(0.4007)$ & $(0.0134)$ & $(0.1614)$ & 0.1598 & 0.1785 \\
\hline & 0.0340 & 0 & -0.0006 & 0.0019 & 0.0347 & 0.0407 & & & 0.0200 & 0.0638 & -0.0051 & 0.0086 & 0.0251 & 0.0552 & & \\
\hline Financials & $(0.4296)$ & $(0.4062)$ & 1) & $(0.9438)$ & $(0.1892)$ & (0.1936) & 0.0519 & 0.0534 & $(0.6233)$ & $(0.2482)$ & $(0.8494)$ & $(0.7705)$ & $(0.3142)$ & $(0.1015)$ & 0.0469 & 0.0608 \\
\hline Healthcare & $(0$ & & & & $\begin{array}{l}-0 \\
(0 .\end{array}$ & $(0.3594)$ & & & $\begin{array}{c}-0.0272 \\
(0.8174)\end{array}$ & $\begin{array}{c}0.0969 \\
(0.3957)\end{array}$ & $\begin{array}{c}0.0540 \\
(0.4664)\end{array}$ & $\begin{array}{c}0.0924 \\
(0.1639)\end{array}$ & $\begin{array}{l}-0.0812 \\
(0.4563)\end{array}$ & $\begin{array}{c}0.0045 \\
(0.9692)\end{array}$ & & \\
\hline & 0.0555 & 0 & -0 & -0.0128 & 0.0569 & 0.0722 & & & 0.0672 & 0.045 & 0.0216 & -0.0386 & 0.0457 & 0.0841 & & \\
\hline Industrials & $(0.2136)$ & $(0$ & $(0.9531)$ & $(0.4942)$ & $(0.0986)$ & $(0.0590)$ & 0.0585 & 298 & $(0.1414)$ & $(0.2371)$ & $(0.3589)$ & $(0.0417)$ & $(0.2022)$ & $(0.0208)$ & 0.0567 & 0.0344 \\
\hline & 0.0746 & -0.2264 & 0.0284 & -0.0439 & 0.0462 & -0.1825 & & & -0.0506 & -0.0550 & 0.0319 & -0.0390 & -0.0825 & -0.0161 & & \\
\hline Oil \& Gas & $(0.5338)$ & $(0.1222)$ & $(0.5898)$ & $(0.0200)$ & $(0.6985)$ & $(0.2098)$ & 0.4213 & 4612 & $(0.6893)$ & $(0.6949)$ & $(0.5875)$ & $(0.0202)$ & $(0.5121)$ & & 0.4133 & 0.4691 \\
\hline & 0.6925 & 0.8861 & -0.0838 & -0.1238 & 0.7763 & 1.009 & & & 0.6455 & 0.8808 & -0.0437 & -0.1465 & 0.6892 & 1.0273 & & \\
\hline Technology & $(0.0001)$ & $(0.0037)$ & $(0.0732)$ & $(0.1018)$ & $(0.0001)$ & $(0.0028)$ & 0.4206 & 0.4365 & $(0.0003)$ & $(0.0007)$ & $(0.2293)$ & $(0.0333)$ & $(0.0003)$ & $(0.0005)$ & 0.4331 & 0.4232 \\
\hline & & 0.0838 & -0.0 & 0.0325 & 0.0484 & 0.0512 & & & 0.0286 & 0.6475 & 0.0027 & 0.8859 & 0.0259 & 0.6557 & & \\
\hline Utilities & $(0.5394)$ & $(0.3623)$ & $(0.7525)$ & $(0.2035)$ & $(0.4735)$ & $(0.5707)$ & 0.1228 & 0.1961 & $(0.1033)$ & $(0.3076)$ & $(0.0213)$ & $(0.3830)$ & $(0.0820)$ & $(0.4211)$ & 0.1107 & 0.2126 \\
\hline
\end{tabular}

This table reports the results for the following equation: $\Delta_{k, t}=\beta_{t} \Delta_{k, t-1}+\varepsilon_{k, t}$. For each security and quarter between June 1995 and September 2008 we calculate the fraction of funds that increase their position in the security in the Spanish market. A fund is defined as increasing its position if it holds a greater fraction of the firm's shares at the end of the quarter than it held at the beginning. All data are standardized (i.e. rescaled to zero mean, unit variance) each quarter. We then estimate quarterly cross-sectional regressions of institutional demand on lagged institutional demand. Because there is a single independent variable in each regression and the data are standardized, these regression coefficients are also the cross-sectional correlations between institutional demand and lagged institutional demand. We then average our results across two distinctive groups, contingent upon whether the quarterly market/sector volume has increased or decreased. The Madrid Stock Exchange General Price Index and our nine sectors' indices are used here to calculate market and sector volumes, respectively. Market/sector volume here is calculated every quarter by aggregating the daily volume observations of the Madrid Stock Exchange General Price Index and our nine sectors' indices every quarter. The first column reports the time-series' averages of these correlation coefficients and associated p-values (in parentheses) for each of the two groups and for each sector, controlling for market (panel A) and sector (panel B) volume separately. The second and third columns report the portion of the correlation that results from funds following their own lagged trades and the portion that results from funds following the previous trades of other funds (herding) for each of the two groups and for each sector, controlling for market (panel A) and sector (panel B) volume separately. 


\begin{tabular}{|c|c|c|c|c|c|c|c|c|c|c|c|c|}
\hline & \multicolumn{3}{|c|}{$\begin{array}{c}\text { Average Coefficient } \\
(\beta)\end{array}$} & \multicolumn{3}{|c|}{ Funds following their own trades } & \multicolumn{3}{|c|}{$\begin{array}{l}\text { Funds following the } \\
\text { trades of other funds }\end{array}$} & \multicolumn{3}{|c|}{ Average $\mathrm{R}^{2}$} \\
\hline & High & Mid & Low & High & Mid & Low & High & Mid & Low & High & Mid & Low \\
\hline \multicolumn{13}{|c|}{ Panel A: Market Volume } \\
\hline Basic & 0.0655 & -0.0337 & -0.0244 & -0.0997 & -0.0019 & -0.0282 & 0.1653 & -0.0317 & 0.0037 & & & \\
\hline Materials & $(0.4802)$ & $(0.6384)$ & $(0.7405)$ & $(0.0646)$ & $(0.9542)$ & $(0.1525)$ & $(0.0500)$ & $(0.5515)$ & $(0.9548)$ & 0.1293 & 0.0835 & 0.0791 \\
\hline Consumer & -0.0697 & -0.0305 & 0.1696 & -0.0689 & -0.0026 & -0.0763 & -0.0008 & -0.0279 & 0.2459 & & & \\
\hline Goods & $(0.3361)$ & $(0.6634)$ & $(0.0206)$ & $(0.0614)$ & $(0.9276)$ & $(0.5292)$ & $(0.9866)$ & $(0.6188)$ & $(0.0505)$ & 0.0843 & 0.0816 & 0.0946 \\
\hline Consumer & 0.2359 & 0.0289 & 0.0553 & -0.0291 & -0.0109 & -0.0936 & 0.2651 & 0.0399 & 0.1490 & & & \\
\hline \multirow[t]{2}{*}{ Services } & $(0.0271)$ & $(0.6930)$ & $(0.6426)$ & $(0.3622)$ & $(0.2971)$ & $(0.1653)$ & $(0.0050)$ & $(0.5755)$ & $(0.1757)$ & 0.1856 & 0.0961 & 0.2247 \\
\hline & -0.0064 & 0.0597 & 0.0584 & -0.0164 & 0.0081 & 0.0091 & 0.0100 & 0.0515 & 0.0493 & & & \\
\hline \multirow[t]{2}{*}{ Financials } & $(0.9141)$ & $(0.3192)$ & $(0.2740)$ & $(0.6459)$ & $(0.8273)$ & $(0.7731)$ & $(0.7719)$ & $(0.1428)$ & $(0.1746)$ & 0.0555 & 0.0575 & 0.0443 \\
\hline & 0.0687 & 0.0151 & 0.0144 & 0.0415 & 0.1190 & 0.0541 & 0.0272 & -0.1039 & -0.0396 & & & \\
\hline \multirow[t]{2}{*}{ Healthcare } & $(0.5680)$ & $(0.9156)$ & $(0.9313)$ & $(0.2136)$ & $(0.0663)$ & $(0.6886)$ & $(0.7827)$ & $(0.5224)$ & $(0.7891)$ & 0.2267 & 0.3362 & 0.4325 \\
\hline & 0.0518 & 0.0728 & 0.0459 & 0.0083 & 0.0112 & -0.0392 & 0.0434 & 0.0616 & 0.0852 & & & \\
\hline \multirow[t]{2}{*}{ Industrials } & $(0.3339)$ & $(0.1569)$ & $(0.4052)$ & $(0.7762)$ & $(0.6832)$ & $(0.1085)$ & $(0.4022)$ & $(0.0785)$ & $(0.0726)$ & 0.0451 & 0.0435 & 0.0507 \\
\hline & 0.0650 & -0.0991 & -0.1213 & -0.0113 & -0.0145 & 0.0201 & 0.0763 & -0.0845 & -0.1414 & & & \\
\hline \multirow[t]{2}{*}{ Oil \& Gas } & $(0.7123)$ & $(0.4397)$ & $(0.5187)$ & $(0.2232)$ & $(0.0907)$ & $(0.8373)$ & $(0.6587)$ & $(0.5008)$ & $(0.4511)$ & 0.4993 & 0.2797 & 0.5508 \\
\hline & 0.6911 & 0.5421 & 1.1354 & -0.0565 & -0.0729 & -0.1790 & 0.7476 & 0.6151 & 1.3144 & & & \\
\hline \multirow[t]{2}{*}{ Technology } & $(0.0035)$ & $(0.0000)$ & $(0.0120)$ & $(0.1023)$ & $(0.3358)$ & $(0.0627)$ & $(0.0031)$ & $(0.0001)$ & $(0.0082)$ & 0.3940 & 0.3560 & 0.5487 \\
\hline & 0.0416 & 0.0704 & 0.0678 & 0.0043 & 0.0439 & -0.0186 & 0.0372 & 0.0264 & 0.0865 & & & \\
\hline Utilities & $(0.6809)$ & $(0.4264)$ & $(0.5220)$ & $(0.8695)$ & $(0.1140)$ & $(0.4086)$ & $(0.7131)$ & $(0.7789)$ & $(0.3461)$ & 0.1695 & 0.1307 & 0.1626 \\
\hline \multicolumn{13}{|c|}{ Panel B: Sector Volume } \\
\hline Basic & 0.0655 & -0.0337 & -0.0245 & -0.0998 & -0.0020 & -0.0283 & 0.1653 & -0.0317 & 0.0038 & & & \\
\hline Materials & $(0.4802)$ & $(0.6384)$ & $(0.7405)$ & $(0.0646)$ & $(0.9542)$ & $(0.1525)$ & $(0.0500)$ & $(0.5515)$ & $(0.9548)$ & 0.1293 & 0.0835 & 0.0791 \\
\hline Consumer & 0.1906 & -0.1305 & 0.0151 & -0.0830 & -0.0689 & 0.0078 & 0.2736 & -0.0617 & 0.0073 & & & \\
\hline Goods & $(0.0268)$ & $(0.0382)$ & $(0.8025)$ & $(0.4973)$ & $(0.0127)$ & $(0.8164)$ & $(0.0327)$ & $(0.2179)$ & $(0.8694)$ & 0.1307 & 0.0719 & 0.0585 \\
\hline Consumer & 0.2362 & 0.0403 & 0.0431 & -0.0170 & -0.0237 & -0.0922 & 0.2532 & 0.0641 & 0.1354 & & & \\
\hline \multirow{2}{*}{ Services } & $(0.0266)$ & $(0.6000)$ & $(0.7125)$ & $(0.5086)$ & $(0.2512)$ & $(0.1725)$ & $(0.0092)$ & $(0.3775)$ & $(0.2097)$ & 0.1873 & 0.1100 & 0.2083 \\
\hline & -0.0246 & 0.0509 & 0.0860 & -0.0195 & -0.0141 & 0.0358 & -0.0050 & 0.0650 & 0.0502 & & & \\
\hline \multirow{2}{*}{ Financials } & $(0.7030)$ & $(0.3519)$ & $(0.1045)$ & $(0.5924)$ & $(0.7164)$ & $(0.2037)$ & $(0.8946)$ & $(0.0354)$ & $(0.1686)$ & 0.0641 & 0.0483 & 0.0454 \\
\hline & 0.0510 & 0.1245 & -0.0836 & -0.0061 & 0.0811 & 0.1419 & 0.0571 & 0.0434 & -0.2255 & & & \\
\hline \multirow{2}{*}{ Healthcare } & $(0.6004)$ & $(0.4136)$ & $(0.6256)$ & $(0.8716)$ & $(0.1214)$ & $(0.3075)$ & $(0.4758)$ & $(0.7772)$ & $(0.1708)$ & 0.1506 & 0.3879 & 0.4539 \\
\hline & 0.0378 & 0.0629 & 0.0706 & -0.0072 & 0.0198 & -0.0327 & 0.0450 & 0.0431 & 0.1033 & & & \\
\hline \multirow{2}{*}{ Industrials } & $(0.4866)$ & $(0.2118)$ & $(0.2047)$ & $(0.8488)$ & $(0.2770)$ & $(0.1532)$ & $(0.3361)$ & $(0.2966)$ & $(0.0263)$ & 0.0442 & 0.0422 & 0.0530 \\
\hline & 0.0423 & -0.0046 & -0.1987 & -0.0096 & 0.0671 & -0.0681 & 0.0519 & -0.0718 & -0.1305 & & & \\
\hline \multirow[t]{2}{*}{ Oil \& Gas } & $(0.8066)$ & $(0.9702)$ & $(0.3049)$ & $(0.2801)$ & $(0.4339)$ & $(0.0389)$ & $(0.7600)$ & $(0.5941)$ & $(0.4784)$ & 0.4783 & 0.2567 & 0.5960 \\
\hline & 0.6911 & 0.5422 & 1.1355 & -0.565 & -0.0729 & -0.1790 & 0.4760 & 0.6151 & 1.3145 & & & \\
\hline \multirow{2}{*}{ Technology } & $(0.0035)$ & $(0.0000)$ & $(0.0120)$ & $(0.1023)$ & $(0.3358)$ & $(0.0627)$ & $(0.0031)$ & $(0.0001)$ & $(0.0082)$ & 0.3940 & 0.3516 & 0.5487 \\
\hline & -0.0282 & 0.1222 & 0.0829 & 0.0026 & 0.0401 & -0.0128 & -0.0308 & 0.0821 & 0.0957 & & & \\
\hline Utilities & $\begin{array}{l}(0.7736) \\
\text { (n) }\end{array}$ & $(0.1785)$ & $(0.4304)$ & $(0.9239)$ & $(0.1401)$ & $(0.5738)$ & $(0.7575)$ & $\begin{array}{l}(0.3884) \\
\text { (n) }\end{array}$ & $(0.2937)$ & 0.1586 & 0.1420 & 0.1616 \\
\hline
\end{tabular}

This table reports the results for the following equation: $\Delta_{k, t}=\beta_{t} \Delta_{k, t-1}+\varepsilon_{k, t}$. For each security and quarter between June 1995 and September 2008 we calculate the fraction of funds that increase their position in the security in the Span estimate quaterly and the data are standardized, these regression coefficients are also the cross-sectional correlations between institutional demand and lagged institutional demand. We then average our results across three distinctive groups, namely "high", "mid" and "low" contingent upon whether the market's/sector's volume during the contemporaneous quarter falls in the top, middle or bottom third of the sample period's quarterly market/sector volume-values ranked in ascending order. Market/sector volume here is calculated every quarter by aggregating the daily volume observations of the Madrid Stock Exchange General Price Index and our nine sectors' indices every quarter. The first column reports the time-series' average of these correlation coefficients and associated p-values (in parentheses) for each of the three groups and for each sector, controlling for market (panel A) and sector (panel B) volume separately. The second and third columns report the portion of the correlation that results from funds following their own lagged trades and the portion that results from funds following the previous trades of other funds (herding) for each of the three groups and for each sector, controlling for market (panel A) and sector (panel B) volume separately. 